\title{
Determination of the most influential and cost-optimal building characteristics on the energy performance of commercial and industrial buildings
}

\author{
Hilde Breesch ${ }^{1, *}$, Barbara Wauman ${ }^{1}$, and Marcus Peeters $^{2}$ \\ ${ }^{1}$ Sustainable Building, Construction Technology Cluster, Department of Civil Engineering, Ghent Technology Campus, KU Leuven, \\ Ghent, Belgium \\ ${ }^{2}$ DUBiT, Odisee, Aalst, Belgium
}

\begin{abstract}
Unlike other types of buildings, commercial and industrial buildings have been so far "forgotten". In addition, EPBD requirements are increasingly challenging for this type of buildings. This paper aims to identify the most building determinants of the energy performance of commercial and industrial buildings, focussing on the building envelope. Building energy simulations (BES) in TRNSYS are used to simulate the energy demand for heating and cooling in five building variants. The Pareto optimality approach that considers the economic and energetic objectives equally, is used to determine the cost-optimal solutions. The sensitivity analysis and cost-optimal study clearly reveal that airtightness seems to be the most important factor. Although heat recovery on a balanced mechanical ventilation system has a major impact on the energy demand for heating, this measure is not cost-optimal. The large impact of the U-value of the roof on the energy demand for heating is also reflected in the cost-optimal study. The insulation of the floor do not appear to be cost-optimal. Moreover, attention to construction detailing is important. The additional energy losses that can occur due to thermal bridges quickly reach significant values although solving the thermal bridges seems not to be cost-optimal.
\end{abstract}

\section{Introduction}

The EPBD regulations for new and renovated buildings are evolving and tightening up (e.g. the recent 2 nd recast of EPBD directive [1]). Unlike other types of buildings, commercial and industrial buildings have been so far "forgotten" buildings. Although the typical construction methods have proven their worth a long time ago, the stricter EPBD requirements are increasingly challenging. These requirements do not reflect the current building practice for this type of buildings. The industrial building methods are distinguished by their high construction speed and low finish. Very little attention is paid to the airtightness of the building envelope and very little information is also available on how airtight industrial and commercial buildings are in reality. Most of the buildings have an uninsulated floor and the avoidance of thermal bridges. Contrary to dwellings and office and school buildings, a lot of uncertainty exists about the efficiency and cost-benefit of energy saving measures in industrial and commercial buildings.

The objective of this paper consists of the identification of the most (building) determinants of the energy performance of commercial and industrial buildings. These measures are also checked on their cost-optimality. In this research the focus is on the building envelope.
First, the representative buildings with their shape, zoning, construction type, use and HVAC are presented. Afterwards, the simulation set up is defined. Section 4 discusses the results of the sensitivity analysis and the cost-optimal study and finally the conclusions are presented.

\section{Representative buildings}

\subsection{Building description}

The representative commercial and industrial buildings are based on similar international research projects [2], [3]. These data are tested against contemporary Flemish building practice and current building regulations for commercial and industrial buildings. In an attempt to take realistic variations in existing Small and Medium Enterprise (SME) buildings into account in a simplified way, building variants are considered with variations of building characteristics like shape and layout.

Two building shapes are considered: (1) a detached building representing commercial (i.e. a large shop) and industrial buildings (i.e. a SME building with storage, distribution or production space) (see Fig. 1) and (2) a collective building representing smaller, connected SME buildings (see Fig. 2). For both building shapes, Table 1

\footnotetext{
* Corresponding author: hilde.breesch@kuleuven.be
} 
shows typical building characteristics. Both buildings include 1 floor with a height of $6 \mathrm{~m}$ and windows are only provided in the facade.

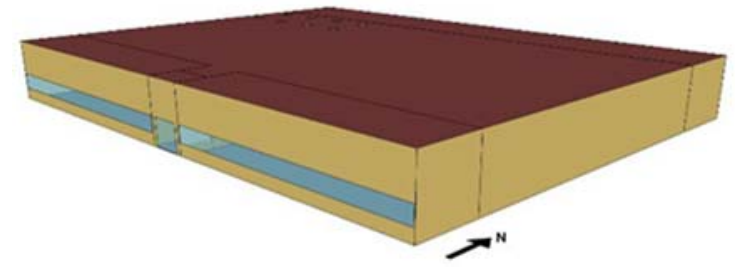

Fig. 1. Detached SME building

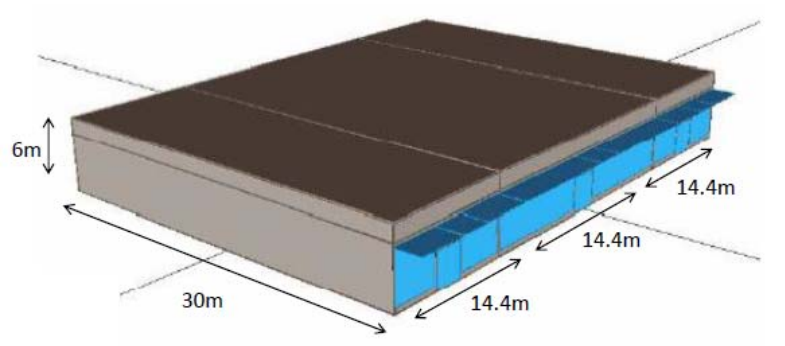

Fig. 2. Collective SME building

Table 1. Building characteristics

\begin{tabular}{|c|c|c|c|}
\hline & WWR (\%) & Afloor $\left(\mathrm{m}^{2}\right)$ & Volume $\left(\mathrm{m}^{3}\right)$ \\
\hline Detached & 25 & 1650 & 9900 \\
\hline Collective & 70 & $432 \times 3$ & $2592 \times 3$ \\
\hline
\end{tabular}

Furthermore, for the selected type buildings, two use scenarios are established based on information from a similar study [4] : (1) commercial building used for sale of products or clothing (see Fig. 3) and (2) industrial building used for logistics, storage and distribution. The zoning of these buildings is shown on (see Fig. 4).

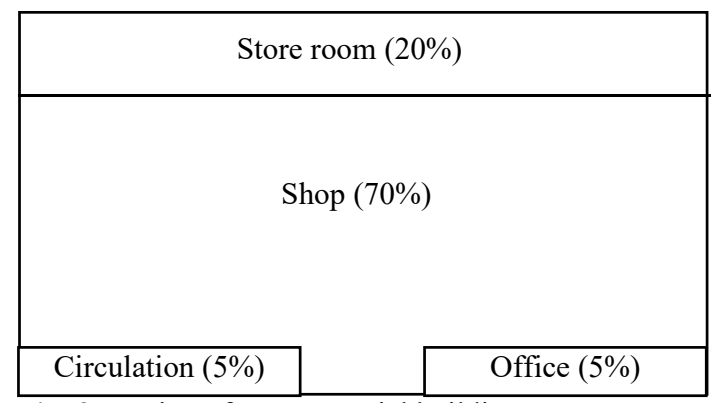

Fig. 3. Zoning of a commercial building

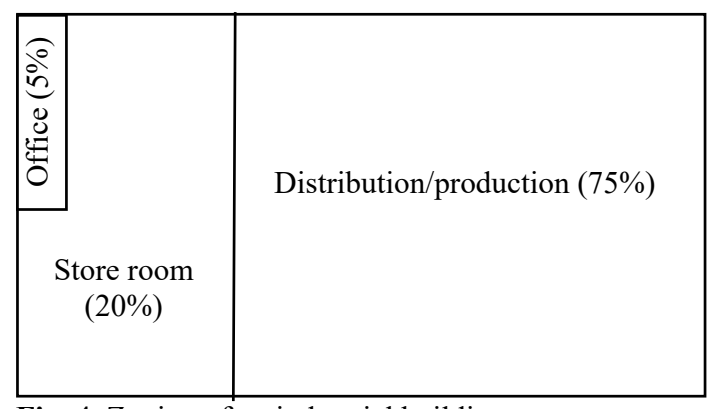

Fig. 4. Zoning of an industrial building
In practice, different building constructions are used in SME buildings. Based on an analysis of the building envelope of existing SME buildings, 3 representative variants for the building envelope composition are determined: (1) complete concrete structure, (2) Liner tray system for outer walls, in combination with concrete floor and steel deck roof plates, (3) steel outer walls and roof sheets, in combination with a concrete floor. The composition of the walls of the different construction types is shown in Table 2.

In order to limit the total number of simulations to be carried out, the number of building variants considered is limited to 5, as shown on Fig. 5.

Table 2. Wall composition

\begin{tabular}{|c|c|c|c|}
\hline & concrete & Liner tray & steel \\
\hline \multirow{3}{*}{ facade } & Concrete $(11 \mathrm{~cm})$ & Steel plate & $\begin{array}{l}\text { Sandwich } \\
\text { panel }\end{array}$ \\
\hline & PUR & \multirow[b]{2}{*}{ MW } & \multirow[b]{2}{*}{ PUR } \\
\hline & concrete $(7 \mathrm{~cm})$ & & \\
\hline \multirow{3}{*}{ roof } & $\begin{array}{l}\text { Concrete TT- } \\
\text { elements }(4 \mathrm{~cm})\end{array}$ & \multirow{3}{*}{$\begin{array}{l}\text { Steel deck } \\
\text { (PUR) }\end{array}$} & \multirow{3}{*}{$\begin{array}{l}\text { Steel deck } \\
\text { (PUR) }\end{array}$} \\
\hline & PUR & & \\
\hline & EPDM & & \\
\hline \multirow{3}{*}{ floor } & Screed $(8 \mathrm{~cm})$ & \multirow{3}{*}{$\begin{array}{l}\text { Idem } \\
\text { concrete }\end{array}$} & \multirow{3}{*}{ Idem concrete } \\
\hline & concrete $(15 \mathrm{~cm})$ & & \\
\hline & PUR & & \\
\hline
\end{tabular}

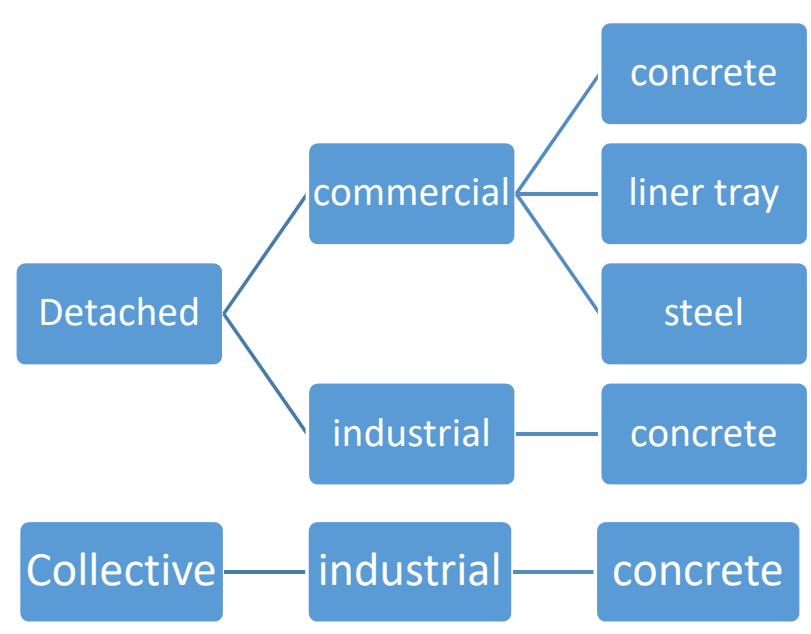

Fig. 5. Overview of building variants

\subsection{Building usage}

Typical usage profiles for the different usage scenarios (sales, distribution and storage) are defined for a 24-hour period for lighting, occupancy (and related internal heat gains by persons) and for ventilation (fraction) based on the activity database [5] which is used in EnergyPlus [6], among other things. As an illustration, the usage diagrams for the different building zones of a commercial building are presented in Fig. 6. Assumptions about occupancy and internal heat gains are summarised in Table 3 and 4. 


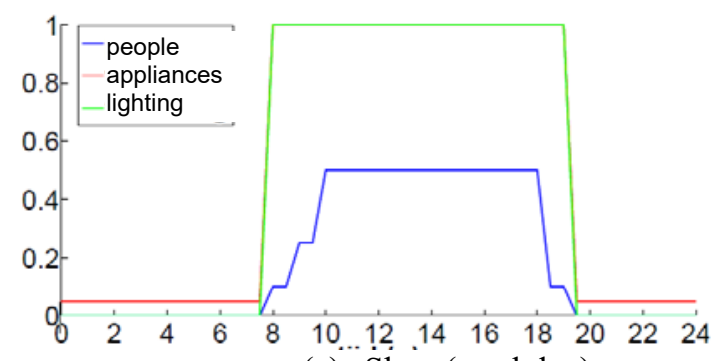

(a) Shop (weekday)

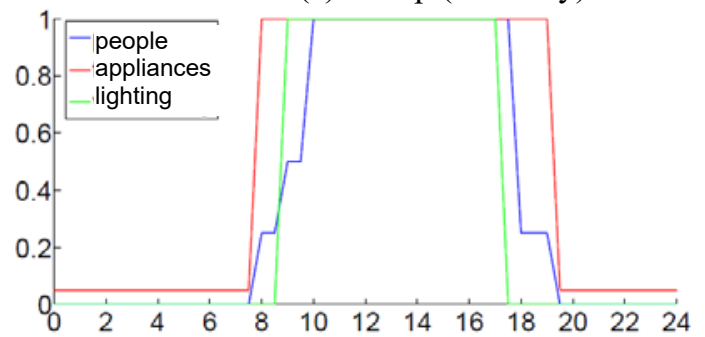

(b) Shop (weekend)

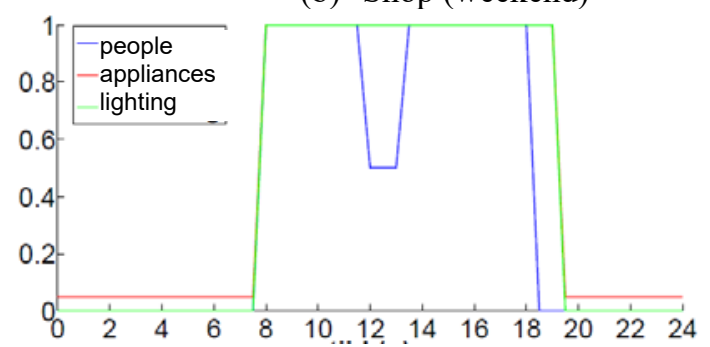

(c) Office

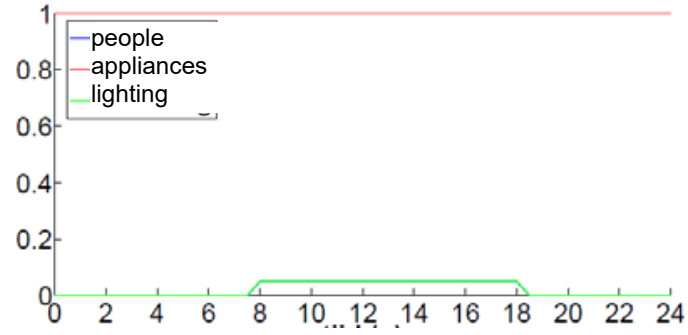

(d) Storeroom

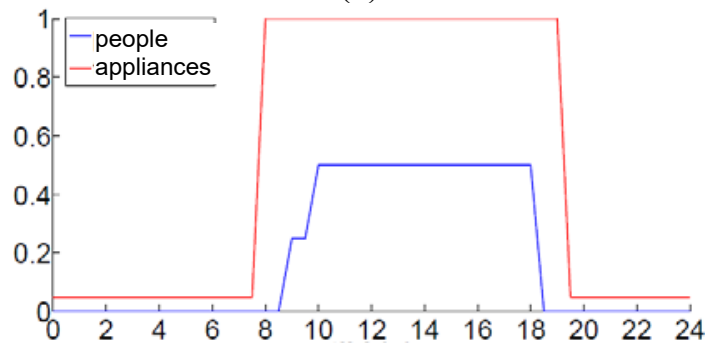

(e) Circulation

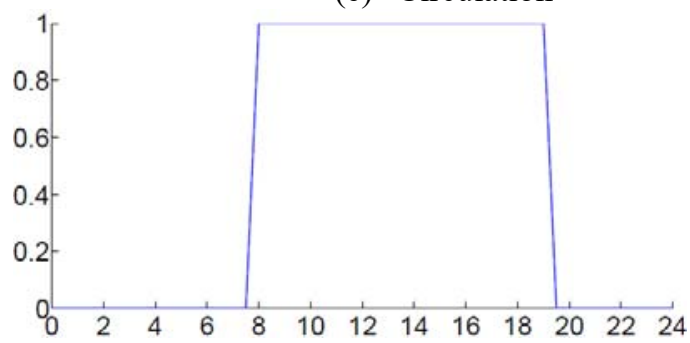

(f) HVAC

Fig. 6. Usage profiles commercial buildings (a) shop (weekday) (b) shop (weekend) (c) office (d) storeroom (e) circulation (f) HVAC
Table 3. Occupancy as function of activity [5]

\begin{tabular}{|c|c|c|}
\hline Occupancy $\left(\mathrm{m}^{2} /\right.$ pers $)$ & commercial & industrial \\
\hline Shop/production & 9.1 & 14.3 \\
\hline office & 14.3 & 14.3 \\
\hline Storeroom & 9.1 & 9.1 \\
\hline circulation & 5 & - \\
\hline
\end{tabular}

Table 4. Internal heat gains of persons and appliances [5]

\begin{tabular}{|c|c|c|c|c|}
\hline \multirow{2}{*}{$\begin{array}{c}\text { Internal } \\
\text { heat gains }\end{array}$} & \multicolumn{2}{|c|}{ commercial } & \multicolumn{2}{c|}{ industrial } \\
\cline { 2 - 5 } & $\begin{array}{c}\text { pers } \\
\text { (W/pers })\end{array}$ & $\begin{array}{c}\text { Applian } \\
\text { ces } \\
\left(\mathrm{W} / \mathrm{m}^{2}\right)\end{array}$ & $\begin{array}{c}\text { pers } \\
(\mathrm{W} / \text { pers })\end{array}$ & $\begin{array}{c}\text { Applian } \\
\text { ces } \\
\left(\mathrm{W} / \mathrm{m}^{2}\right)\end{array}$ \\
\hline $\begin{array}{c}\text { Shop } \\
\text { production }\end{array}$ & 120 & 5 & 180 & 5 \\
\hline office & 120 & 10 & 120 & 10 \\
\hline Storeroom & 120 & 25 & 140 & 2 \\
\hline circulation & 120 & 5 & - & - \\
\hline
\end{tabular}

\subsection{HVAC and lighting}

Since the focus of the research project is limited to the evaluation of measures on the building envelope and thus to the evaluation of the energy demand, the systems for climate control are included in a simplified way. An ideal system (i.e. perfect control, unlimited heating and cooling capacity) is assumed for both heating and cooling. The calculated heating and cooling requirements represent the amount of energy ideally required to guarantee the comfort levels of $20^{\circ} \mathrm{C}$ in a shop, minimum $20^{\circ} \mathrm{C}$ and maximum $29^{\circ} \mathrm{C}$ in offices and minimum $15.6^{\circ} \mathrm{C}$ in store and distribution rooms [2], [3], [4]. An intermittent heating and cooling system is assumed, whereby the temperature is lowered and increased respectively at night and during weekends. The setback is set $5^{\circ} \mathrm{C}$ for heating and $30^{\circ} \mathrm{C}$ for cooling.

In accordance with the indoor air quality requirements as specified in EN 15251 [7], the intended ventilation rate in each zone is determined as the maximum of 30 $\mathrm{m}^{3} /$ (h.pers) and $1.3 \mathrm{~m}^{3} /\left(\mathrm{h} \cdot \mathrm{m}^{2}\right)$. The ventilation is timecontrolled according to the current occupancy schedules. In case of a mechanical ventilation system with heat recovery is foreseen, the efficiency of the heat exchanger is equated to $75 \%$. In addition, a bypass is installed which is switched on as soon as (1) the supply air temperature > $22^{\circ} \mathrm{C}$ and (2) the outdoor temperature $<$ indoor temperature and $>14{ }^{\circ} \mathrm{C}$ (occupied) or $>10^{\circ} \mathrm{C}$ (not occupied).

The installed lighting capacity for the different building zones is shown in Table 5, the use in Fig. 6 (f). 
Table 5. Installed lighting capacity [5]

\begin{tabular}{|c|c|c|}
\hline $\begin{array}{c}\text { Installed lighting } \\
\text { capacity }\left(\mathrm{W} / \mathrm{m}^{2}\right)\end{array}$ & commercial & industrial \\
\hline Shop/production & 10 & 10 \\
\hline office & 10 & 10 \\
\hline Storeroom & 0 & 0 \\
\hline
\end{tabular}

\section{Method}

Building Energy Simulations (BES) are used to determine the most influential and cost-optimal building characteristics of commercial and industrial buildings. The net energy demand for heating and cooling are calculated with the simulation tool TRNSYS [8] with weather data of Ukkel (Belgium) [9] in the representative buildings. A parameter, sensitivity analysis and costoptimal study are carried out to determine the most influential and cost-optimal building parameters.

\subsection{Parameter and sensitivity analysis}

In order to define the determining factors for the energy demand for heating and cooling, a parameter study is carried out. The influence of the energy efficiency of the building envelope ( $\mathrm{U}$-value, airtightness $\mathrm{n}_{50}$ ), the presence of thermal bridges, the provision of sun protection and the impact of heat recovery on the ventilation air on the energy demand is studied. Table 6 shows the minimum, maximum value and the amount of intermediate values for these parameters.

Table 6. Parameter study : range of building parameters

\begin{tabular}{|c|c|c|c|}
\hline & $\begin{array}{c}\text { Min } \\
\text { value }\end{array}$ & Max value & $\begin{array}{c}\text { Intermediate } \\
\text { values }\end{array}$ \\
\hline $\begin{array}{c}\mathrm{U}_{\text {wall/roof/floor }} \\
\mathrm{W} /\left(\mathrm{m}^{2} \mathrm{~K}\right)\end{array}$ & 0.10 & 0.24 & 4 \\
\hline $\begin{array}{c}\mathrm{U}_{\text {window glazing }} \\
\mathrm{W} /\left(\mathrm{m}^{2} \mathrm{~K}\right)\end{array}$ & 0.6 & 1.1 & 1 \\
\hline $\begin{array}{c}\mathrm{U}_{\text {window profile }} \\
\mathrm{W} /\left(\mathrm{m}^{2} \mathrm{~K}\right)\end{array}$ & 0.8 & 2.9 & 1 \\
\hline $\mathrm{g}_{\text {window glazing }}$ & 0.26 & 0.6 & 4 \\
\hline $\begin{array}{c}\text { External solar } \\
\text { shading }\end{array}$ & No & yes & - \\
\hline $\begin{array}{c}\text { Air tightness: } \\
\mathrm{n}_{50}\left(\mathrm{~h}^{-1}\right)\end{array}$ & 0.5 & 5.4 & 4 \\
\hline Thermal bridges & No & yes & - \\
\hline $\begin{array}{c}\text { Heat recovery } \\
\text { ventilation }(\%)\end{array}$ & 0 & 75 & - \\
\hline
\end{tabular}

Furthermore, the sensitivity of the heating and cooling demand to each building parameter is expressed using the standardized correlation coefficient (without units), taking into account the standard deviation of the range of each parameter.

\subsection{Cost-optimal study}

The cost-optimal study is carried out according to the methodology laid down in the Commission delegated regulation of 16 January 2012 [10] and the European Standard EN 15459-1 [11].

The measures applied to the type of buildings via BES simulations are evaluated on the basis of the Net Present Cost (NPC). The NPC represents the sum of the initial investment and all annual costs (i.e. energy and maintenance costs) and residual values discounted to the investment start year (year zero) based on the real market interest rate and the useful lifespan as defined in EN 15459-1.

The NPC is plotted against total primary energy consumption, calculated from the results of the BES simulations. The primary energy consumption is the sum of the energy consumption for natural gas and electricity. The conversion factors used to calculate primary energy consumption on the basis of the end energy use for natural gas and electricity are 1 and 2.5 respectively.

The Pareto optimality approach that considers the economic and energetic objectives equally, is used to determine the optimal solutions, which are also referred to as non-dominated or Pareto solutions. A solution is called non-dominated if no other feasible measure can be found that improves one objective without causing simultaneous deterioration of the other objective [12]. The combination of all non-dominated solutions is called the Pareto Front. The cost-optimum is the specific data point on the Pareto front with the lowest cost.

Following assumptions are made. Initial investment costs include VAT and are based on a Flemish study for costoptimal energy performance in non-residential buildings [13]. Annual maintenance costs and lifespan are only included for ventilation, cooling, heating and sun screens and based on EN 15459-1. Annual energy costs only take into account energy for heating, cooling and ventilation and are based on energy prices for non-residential use as stated on Eurostat [14]. Price for electricity and natural gas are assumed to be respectively $0.13068 € / \mathrm{kWh}$ and $0.058124 € / \mathrm{kWh}$. Increase of these energy prices is assumed according to the guidelines of the European Commission [10]. Lifespan of each measure is defined in EN 15459-1. When the life expectancy of a certain energy efficiency measure is shorter than the considered life span of the building, replacement costs are included in the costoptimal study for this specific measure. When life expectancy is longer, a residual value is calculated for HVAC system components by a linear depreciation of the initial investment. Disposal costs are not considered in this study. A life span of 20 years is considered for industrial and commercial buildings. The discount rate determines the weight placed on investments in the present versus future costs and benefits. From microeconomic point of view, the discount rate has to reflect the opportunity cost of capital or the expected rate of return for the building owner. The discount rate is assumed to be $4 \%$, according to the Flemish study for cost-optimal energy performance in non-residential buildings [13]. 


\section{Results and discussion}

\subsection{Parameter and sensitivity analysis}

The results of the parameter analysis are graphically presented using box plots, showing the maximum, upper quartile, median, quartile below and minimum of all the simulation results. As an example, the results of the detached commercial building with a steel structure are shown. Fig. 7 (a) to (h) shows the results for the annual net energy demand for heating $\mathrm{Q}_{\mathrm{H}, \mathrm{nd}}$ (expressed per $\mathrm{m}^{2}$ floor area). Table 7 and 8 show the standardized correlation coefficient for net energy demand for heating in order of impact in respectively a detached commercial building (building variants $n^{\circ} 1$ to 3 ) and a concrete industrial building (building variants $\mathrm{n}^{\circ} 4$ and 5).

These results show that the choice of the ventilation system - or rather the presence of a heat exchanger - and the airtightness are the most influential factors for both the energy demand for heating and cooling. Furthermore, with decreasing U-values of the building envelope, the energy demand for heating decrease while the cooling demand increase. Although the impact of better insulation of the building envelope (especially $U_{\text {roof }}$ ) is slightly more significant in the case of a balanced mechanical ventilation system with heat exchanger, the influence of the U-values on the energy consumption is generally limited. The standardized correlation coefficients (SCC) vary between $\mathrm{SCC}_{\text {Ufloor }}=0.03$ and $\mathrm{SCC}_{\text {Uroof }}=0.3$ for heating and between $\mathrm{SCC}_{\text {Uwall }}=-0.11$ and $\mathrm{SCC}_{\text {Ufloor }}=0.4$ for cooling. This parameter study already assumes that the building envelope is (reasonably) well insulated. As a result, the transmission losses are limited and the ventilation losses are proportionally more important. The latter explains the significant influence of heat exchanger (HX) $\left(\mathrm{SCC}_{\mathrm{HX}}=-0.56\right.$ to -0.65$)$ and airtightness of the envelope $\left(\mathrm{SCC}_{\mathrm{n} 50}>0.8\right)$ on the energy need on the one hand and the limited impact of the U-values on the other hand. Moreover, the low impact of the floor insulation on the energy requirement for heating is particularly striking $\left(\mathrm{SCC}_{\text {Ufloor }}=0.03\right)$. On the other hand, the cooling demand increases by $\pm 45 \%$ because the thermal capacity of the underlying soil massif is shorted. It can be concluded that a further reduction of the U-values $\left(<0.24 \mathrm{~W} /\left(\mathrm{m}^{2} . \mathrm{a}\right)\right)$ will only yield limited profit, especially in case of insulating the floor.

The simulation results also show that the energy demand for heating is significantly influenced by the presence of thermal bridges. The influence of extra linear heat losses at the roof edge, concrete plinth and the vertical wall connections is determined. The simulation results show that tackling these thermal bridges reduce the energy demand for heating in the same order of magnitude as the energy savings by reducing the U-value of the envelope. In terms of cooling demand, the impact of the presence of automatic controlled solar protection or sun protection glazing is limited. This low influence may be explained by the fact that windows are north facing and that window surfaces - and thus solar gains - are generally limited.
Finally, the robustness of the results is examined. When the simulation results of the 5 cases (see Fig. 5) are compared, it appears that comparable results are obtained. The influence of the use (= comparison commercial versus industrial, detached, concrete, see Table 7 and 8) of the building is limited. For industrial and commercial buildings, the same most influential parameters are obtained: airtightness, the presence of a heat exchanger and $\mathrm{U}_{\text {roof. }}$ The corresponding values for the standardized correlation coefficients (SCC) differ slightly. Furthermore, $\mathrm{SCC}_{\text {glazing }}$ and $\mathrm{SCC}_{\text {window profile }}$ are lower in industrial buildings. This is due to the difference in window-to-wall fraction (WWR) $\left(\mathrm{WWR}_{\text {industrial }}=25 \%\right.$ compared to $\mathrm{WWR}_{\text {commercoam }}=70 \%$ ). Furthermore, similar decisions are also obtained when evaluating the robustness by building shape (see Table 8 ). Only the influence of the thermal bridges and floor insulation differs slightly. Since in the collective building several SME buildings are linked to each other, the number of thermal bridges is limited by vertical wall construction, resulting in a lower value for $\mathrm{SCC}_{\text {thermal bridges. The }}$ $\mathrm{SCC}_{\text {Ufloor, }}$ on the other hand, is slightly higher for the collective business building, because of the more limited floor space, proportionally larger perimeter and thus higher transmission losses through the floor.

Table 7. Sensitivity analysis : standardized correlation coefficient (SCC) for net energy demand for heating in detached commercial building in order of impact ( ${ }^{\circ} 1$ to 3 )

\begin{tabular}{|c|c|c|c|}
\hline & Concrete & Liner tray & steel \\
\hline $\mathrm{SCCn}_{50}$ & 0.84 & 0.83 & 0.83 \\
\hline $\mathrm{SCC}_{\mathrm{HX}}$ & -0.56 & -0.56 & -0.55 \\
\hline $\mathrm{SCC}_{\text {Uroof }}$ & 0.28 & 0.28 & 0.28 \\
\hline $\begin{array}{c}\mathrm{SCC}_{\text {Uwindow }} \\
\text { glazing }\end{array}$ & 0.19 & 0.19 & 0.19 \\
\hline $\begin{array}{c}\mathrm{SCC}_{\text {Uwindow }} \\
\text { profile }\end{array}$ & 0.18 & 0.18 & 0.18 \\
\hline $\mathrm{SCC}_{\text {Thermal bridges }}$ & 0.08 & 0.17 & 0.17 \\
\hline $\mathrm{SCC}_{\text {Uwall }}$ & 0.12 & 0.10 & 0.13 \\
\hline $\mathrm{SCC}_{\text {Ufloor }}$ & 0.03 & 0.03 & 0.03 \\
\hline
\end{tabular}

Table 8. Sensitivity analysis : standardized correlation coefficient (SCC) for net energy demand for heating in concrete industrial building in order of impact ( $\mathrm{n}^{\circ} 4$ and 5)

\begin{tabular}{|c|c|c|}
\hline & detached & collective \\
\hline $\mathrm{SCCn}_{50}$ & 0.84 & 0.83 \\
\hline $\mathrm{SCC}_{\text {HX ventilation }}$ & -0.65 & -0.65 \\
\hline $\mathrm{SCC}_{\text {Uroof }}$ & 0.26 & 0.27 \\
\hline $\mathrm{SCC}_{\text {Uwall }}$ & 0.12 & 0.16 \\
\hline $\mathrm{SCC}_{\text {Thermal bridges }}$ & 0.08 & 0.01 \\
\hline $\mathrm{SCC}_{\text {Uwindow glazing }}$ & 0.06 & 0.06 \\
\hline $\mathrm{SCC}_{\text {Uwindow profile }}$ & 0.06 & 0.06 \\
\hline $\mathrm{SCC}_{\text {Ufloor }}$ & 0.02 & 0.04 \\
\hline
\end{tabular}




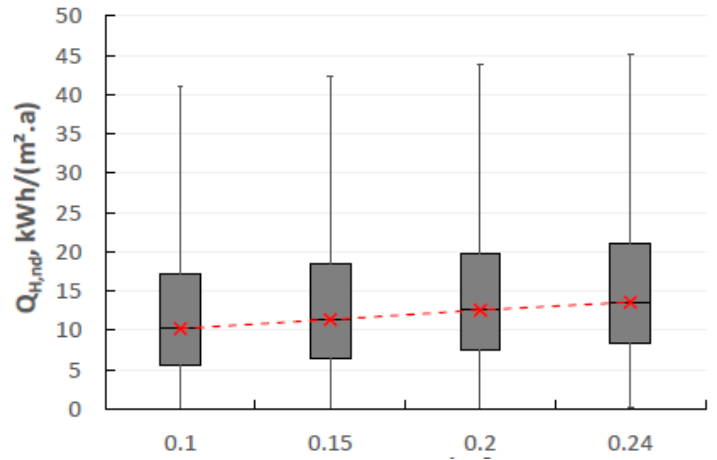

(a) $\mathrm{U}_{\text {wall }}$

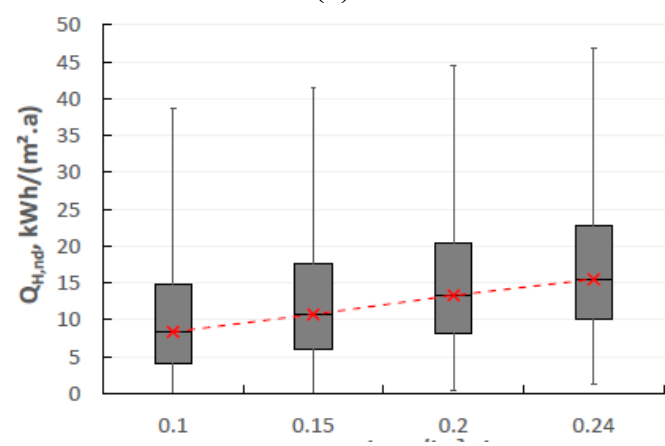

(b) $U_{\text {roof }}$

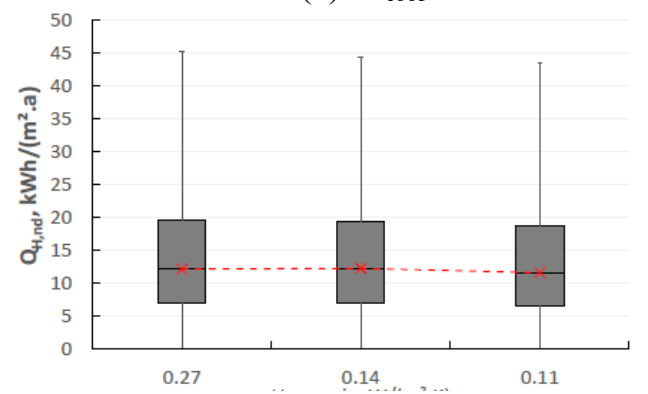

(c) Ufloor

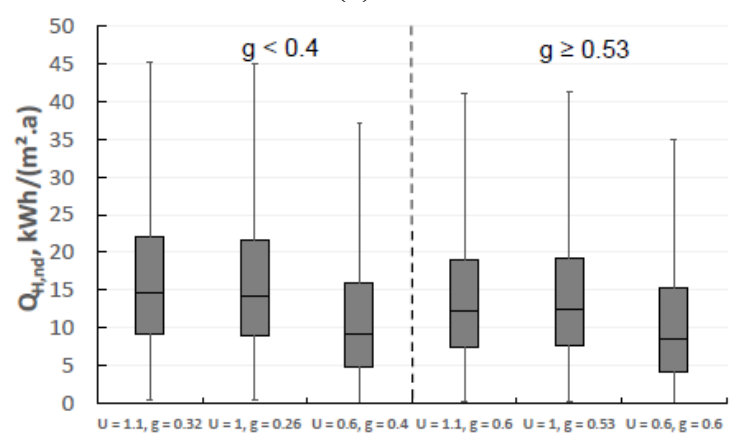

(d) Type of window glazing

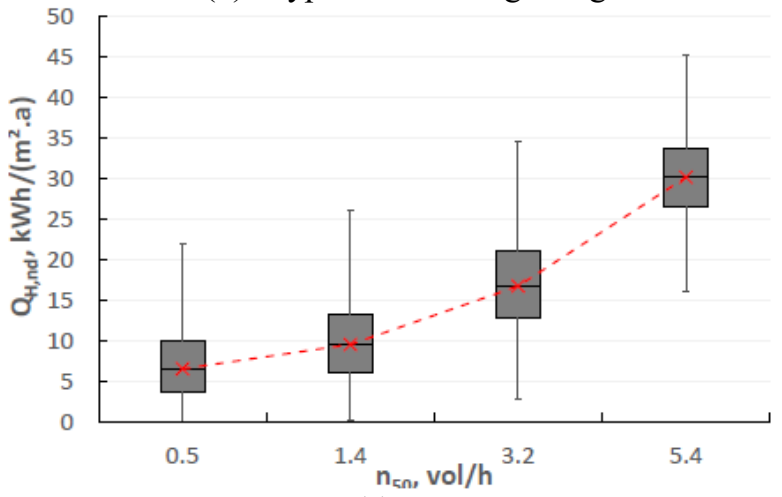

(e) $\mathrm{n}_{50}$

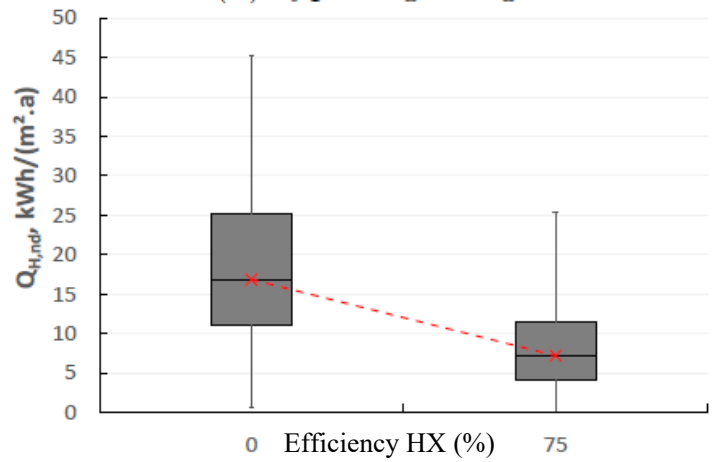

(f) Heat exchanger (HX) efficiency

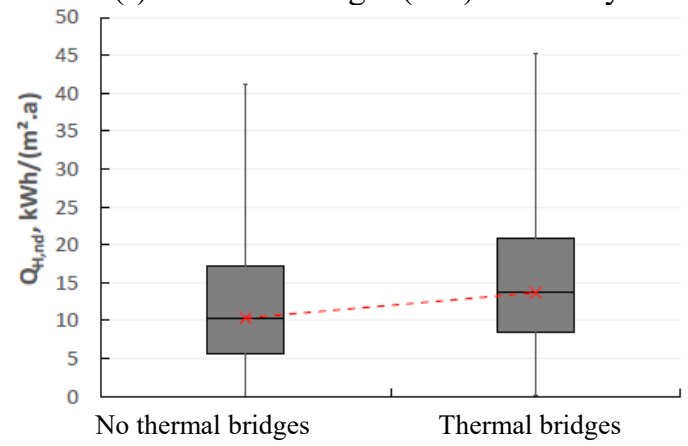

(g) Presence of thermal bridges

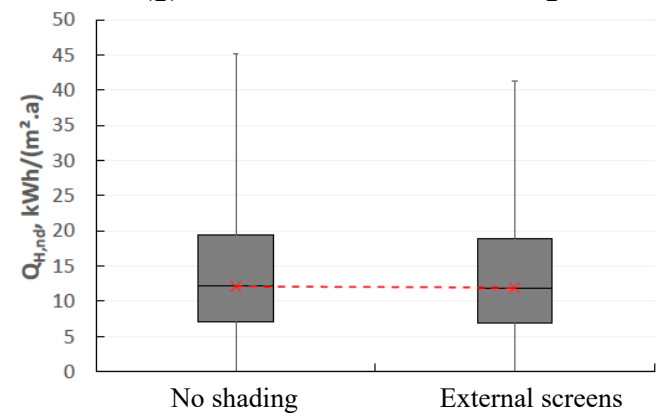

(h) External solar shading

Fig. 7. Boxplots (box $=25-75 \%$, fault bars $=0-100 \%$ ) for net energy demand for heating $\left(\mathrm{QH}_{\mathrm{H}, \mathrm{nd}}\right)$ of a detached, commercial building with a steel building envelope (red crosses indicate the medians). Impact of (a) $U_{\text {wall }}$ (b) $U_{\text {roof }}$ (c) $U_{\text {floor }}(d)$ type of window glazing (e) air tightness $n_{50}$ (f) efficiency of heat exchanger $(\mathrm{g})$ presence of thermal bridges $(\mathrm{h})$ external solar shading

\subsection{Cost optimal solutions}

Fig. 8 shows the NPC as a function of the total primary energy for a detached commercial building with steel outer walls and roof sheets (building variant $n^{\circ} 3$ ). The pareto front is indicated in orange and the cost-optimal solution in red on Fig. 8. Table 9 summarizes the costoptimal solutions of all 5 building variants as defined in Fig. 5. The cost-optimal solution for all the building variants includes a very airtight envelope, a low U-value of the roof, window profile and window glazing and a low g-value of the window. For all the SME buildings, measures like lowering the U-value of the floor and the walls and installing heat recovery on the ventilation system are not cost-optimal. Solution of the thermal bridges is not cost-optimal in all variants caused by the investment cost to eliminate these thermal bridges. 


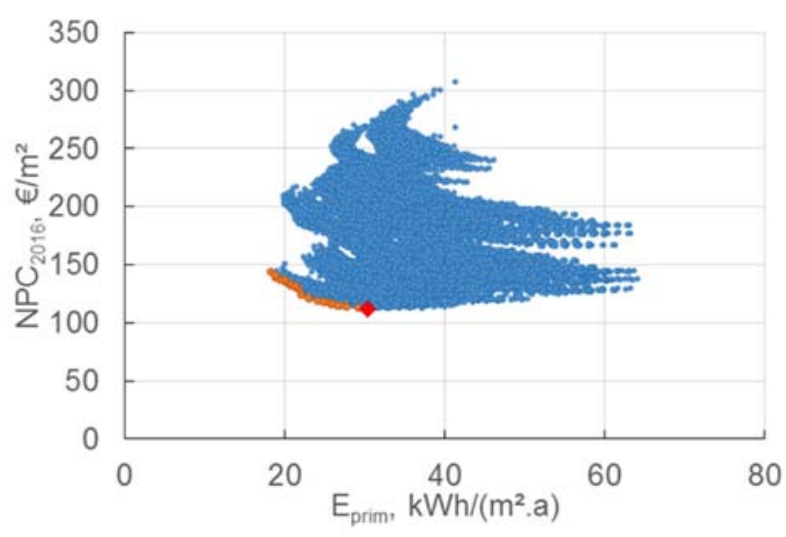

Fig. 8. Cost diagram for a detached commercial building with steel outer walls and roof sheets (building variant $n^{\circ} 3$ )

Table 9. cost-optimal solutions of all building variants

\begin{tabular}{|c|c|c|c|c|c|}
\hline $\begin{array}{c}\text { Building } \\
\text { variant }\end{array}$ & 1 & 2 & 3 & 4 & 5 \\
\hline $\begin{array}{c}\mathrm{U}_{\text {wall }} \\
\mathrm{W} /\left(\mathrm{m}^{2} \mathrm{~K}\right)\end{array}$ & 0.24 & 0.24 & 0.24 & 0.24 & 0.24 \\
\hline $\begin{array}{c}\mathrm{U}_{\text {floor }} \\
\mathrm{W} /\left(\mathrm{m}^{2} \mathrm{~K}\right)\end{array}$ & 0.27 & 0.27 & 0.27 & - & 0.29 \\
\hline $\begin{array}{c}\mathrm{U}_{\text {roof }} \\
\mathrm{W} /\left(\mathrm{m}^{2} \mathrm{~K}\right)\end{array}$ & 0.20 & 0.20 & 0.20 & 0.2 & 0.24 \\
\hline $\begin{array}{c}\mathrm{U}_{\text {window glazing }} \\
\mathrm{W} /\left(\mathrm{m}^{2} \mathrm{~K}\right)\end{array}$ & 0.6 & 1.0 & 1.0 & 0.6 & 1.1 \\
\hline $\begin{array}{c}\mathrm{U}_{\text {window profile }} \\
\mathrm{W} /\left(\mathrm{m}^{2} \mathrm{~K}\right)\end{array}$ & 1.8 & 1.8 & 1.8 & 0.8 & 1.8 \\
\hline $\mathrm{g}_{\text {window glazing }}$ & 0.4 & 0.26 & 0.26 & 0.6 & 0.6 \\
\hline \begin{tabular}{c}
$\mathrm{n} 50\left(\mathrm{~h}^{-1}\right)$ \\
\hline $\begin{array}{c}\text { Thermal } \\
\text { bridges }\end{array}$
\end{tabular} & 0.5 & 1.4 & 0.5 & 0.5 & 0.5 \\
\hline $\begin{array}{c}\text { Heat } \\
\text { recovery }\end{array}$ & no & no & no & No & No \\
\hline $\begin{array}{c}\text { Qheat } \\
\left(\mathrm{kWh} / \mathrm{m}^{2} . \mathrm{a}\right)\end{array}$ & 9.0 & 21.5 & 16.7 & 6.9 & 19.5 \\
\hline $\begin{array}{c}\mathrm{Q}_{\text {cool }} \\
\left(\mathrm{kWh} / \mathrm{m}^{2} . \mathrm{a}\right)\end{array}$ & 13.3 & 7.4 & 9.1 & - & - \\
\hline $\begin{array}{c}\mathrm{E}_{\text {primair }} \\
\left(\mathrm{kWh} / \mathrm{m}^{2} . \mathrm{a}\right)\end{array}$ & 23.7 & 35.0 & 30.3 & 9.2 & 14.6 \\
\hline $\begin{array}{c}\mathrm{NPC} \\
\left(€ / \mathrm{m}^{2}\right)\end{array}$ & 103 & 142 & 112 & 59 & 24 \\
\hline
\end{tabular}

\section{Conclusions}

The parameter analysis and cost-optimal study reveal the factors that have an impact on the energy performance of industrial and commercial buildings.

Airtightness seems to be the most important factor from both analyses. Furthermore, although heat recovery on a balanced mechanical ventilation system has a major impact on the energy demand for heating, this measure is not cost-optimal. This result can be explained by the high investment cost and the extra energy consumption caused by this system. However, it should be noted that no flow control or other controls are provided that could significantly reduce electricity consumption. The large impact of the U-value of the roof on the energy demand for heating is also reflected in the cost-optimal study.
The U-value of the window glazing and profile, the facade and the presence of the thermal bridges have a similar effect on the energy demand for heating. However, this is not always the case in the cost-optimal study. For the commercial building, which has a lot more window area than the industrial building, an improved U-value of the window frame and glazing is cost-optimal. Moreover, this glazing has always solar protection properties. For the industrial building type, changing the window glazing type is not cost-optimal.

Floor insulation is a special case. If the entire floor area of a large building is insulated, the effect on the energy need for heating is minimized but the energy need for cooling significantly increases. This effect is caused by the buffering capacity of the soil, which is closed in case of floor insulation under the floor slab. The heat can no longer be stored in the soil, which increases the cooling requirement. Moreover, the insulation of the floor do not appear to be cost-optimal. The non-insulated floor emerges as a cost-optimal solution, although the U-value is higher than the EPBD requirements.

Solving the thermal bridges seems not to be cost-optimal, keeping in mind that within this study only takes into account the thermal aspect.

For each of the five building variants, implementing the cost-optimal measures means a cost saving over the entire life span. Investing in increasing the energy performance of commercial and industrial building always pays.

\section{References}

1. EPBD, The Revised Energy Performance of Buildings Directive (EU) 2018/844 (2018).

2. B. Liu, R. E. Jarnagin, D. W. Winiarski, W. Jiang, M. F. Mcbride, and G. C. Crall, Technical Support Document: The Development of the Advanced Energy Design Guide for Small Retail Buildings (2006).

3. E. Bonnema, M. Leach, and S. Pless, Technical Support Document: Development of the Advanced Energy Design Guide for Medium to Big Box Retail Buildings - 50 \% Energy Savings Technical Support Document: Development of the Advanced Energy Design Guide for Medium to Big Box Retail Buildings - (2013).

4. B. Lee, M. Trcka, and J. L. M. Hensen, Int. J. LowCarbon Technol. 9, 319 (2014).

5. Department for Communities and Local Government, National Calculation Methodology (NCM) Modelling Guide (for Buildings Other than Dwellings in England and Wales) (London, United Kingdom, 2008).

6. EnergyPlus, Version 9.0.1 (US Department of Energy, 2018).

7. EN 15251, Indoor Environmental Input Parameters for Design and Assessment of Energy Performance of Buildings Addressing Indoor Air Quality, 
Thermal Environment, Lighting and Acoustics (Brussels, Belgium, 2007).

8. S. Klein, W. Beckham, and D. Mitchell, TRNSYS 17.1: A Transient System Simulation Program (Madison, USA, 2010).

9. Meteotest, Meteonorm 5.1 (2005).

10. European Commission, Off. J. Eur. Union 55, 1 (2012).

11. EN 15459-1, Energy Performance of Buildings Economic Evaluation Procedure for Energy Systems in Buildings - Part 1: Calculation Procedures, Module M1-14 (Brussels, Belgium, 2017).

12. G. Verbeeck, Optimisation of Extremely Low Energy Residential Buildings, KU Leuven, 2007.

13. V. Vergaert, W. Parys, and M. Debruyn, Studie Naar Kostenoptimale Niveaus van de Minimumeisen Inzake Energieprestaties van NietResidentiële Gebouwen (2015).

14. Eurostat, Electricity Price Statistics - Statistics Explained (2018). [Online]. Available: http://ec.europa.eu/eurostat/statisticsexplained/index.php?title=Electricity_price_statisti cs. [Accessed: 14-Dec-2018]. 